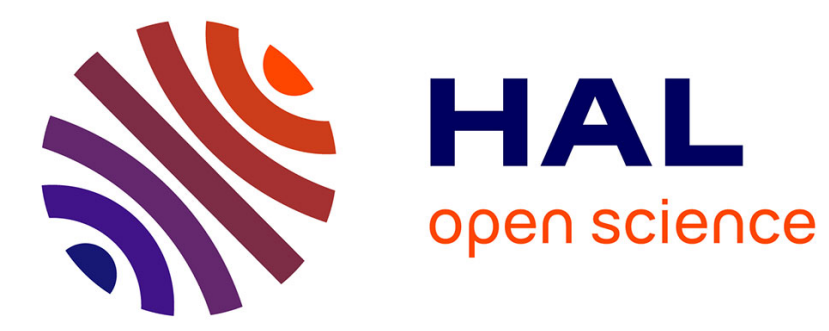

\title{
Canals spawn dams? Exploring the filiation of hydraulic infrastructure
}

\author{
J. Trottier, Sara Fernandez
}

\section{To cite this version:}

J. Trottier, Sara Fernandez. Canals spawn dams? Exploring the filiation of hydraulic infrastructure. Environment and History, 2010, 16 (1), p. 97 - p. 123. 10.3197/096734010X485319 . hal-00612900

\section{HAL Id: hal-00612900 https://hal.science/hal-00612900}

Submitted on 1 Aug 2011

HAL is a multi-disciplinary open access archive for the deposit and dissemination of scientific research documents, whether they are published or not. The documents may come from teaching and research institutions in France or abroad, or from public or private research centers.
L'archive ouverte pluridisciplinaire HAL, est destinée au dépôt et à la diffusion de documents scientifiques de niveau recherche, publiés ou non, émanant des établissements d'enseignement et de recherche français ou étrangers, des laboratoires publics ou privés. 


\title{
Canal Spawn Dams?
}

\section{Exploring the Filiation of Hydraulic Infrastructure}

\author{
JULIE TROTTIER \\ CNRS, FRE 3017, ART-Dev \\ Université Paul Valéry \\ Route de Mende \\ 34199 Montpellier, Cedex 5 \\ FRANCE \\ julie.trottier@univ-montp3.fr
}

\section{SARA FERNANDEZ}

Plan Bleu

15 Rue Beethoven - Sophia Antipolis

06560 Valbonne

FRANCE

sfernandez@planbleu.org

\begin{abstract}
This article studies the aetiology underlying water management by exploring the social hermeneutics that determined its construction. It details how science, technology and political relations construct each other mutually, both producing and harnessing the scientific discourse on the environment. Supply management continues to prevail, in spite of contradictory claims, through the filiation process linking successive generations of water infrastructure. The case study of the Neste Canal inducing the construction of the Charlas Dam, allows the identification of three types of mechanisms participating in the construction of water deficits that now lead both proponents and opponents of dam construction to harness the environmental discourse. The first lies in the social construction of water science and technology. The second lies in the evolution of power relations among the various actors. The third lies in the insertion of the 'expert' within these power relations.
\end{abstract}

\section{KEYWORDS}

Water politics, sociology of science, water scarcity, environmental narrative 


\section{INTRODUCTION}

The overexploitation and degradation of natural resources, especially water, is often attributed to population growth, climate change and inappropriate technology within a theoretical framework that portrays both problem and solution as technical and universal in relevance and application. The 'tragedy of the commons' with its vision of linear development and its ignorance of communal forms of social organisations, still structures the approach of much of the literature devoted to water magement 1. When turning to water, political scientists usually distinguish the scientists who are supposed to provide objective facts concerning it from political actors and activists who struggle to determine its control. This dichotomy is prevalent among French political scientists studying the environment in general. ${ }^{2}$

Accounts of water development in France have been structured by this hypothetical dichotomy as authors have portrayed it up to the 1990s as a state led initiative where engineers, structured in corps, elaborated scientific solutions with hardly any interference from non-state actors. Such accounts have portrayed the discourse on public participation in water management as a novelty that arose only in the last twenty years, a time before which non state actors supposedly didn't play a role in this domain. ${ }^{3}$

Political ecology emerged as a distinct field in the 1980s in response to the perceived apolitical nature of the mainstream literature on sustainable development ${ }^{4}$. The various approaches that came to be designated under this umbrella label initially focussed on developing world case studies and often emphasized aspects of environmental justice. Recently, attempts have been made to combine a political ecology approach with that developed by the sociology of scientific knowledge when examining environmental debates. Such a combined approach focuses on environmental discourses and environmental activism as hybrid objects without supposing 'scientific facts' to provide a pre-established, objective basis for the debate, but rather treating them as social constructs ${ }^{5}$. Forsyth, for example, argues that the political struggles and debates do not occur once the objective facts have been established by the scientists. Both the political struggle and the production of the scientific discourse and technology are deeply enmeshed in one another. These two processes occur concurrently and shape each other ${ }^{6}$.

Forsyth specifically criticized the 'liberation ecology' advocated by Peet and Watts for allowing a projection of values on marginalized actors, often leading to 'solutions' that impoverish them ${ }^{7}$. Wendy Espeland investigated such distortions of the values of local actors 
within her seminal study of the application of rational choice theories to water management in the western United States. ${ }^{8}$ Yet, such an approach remains rare when scientists turn to water management, whether in the industrialized or the developing world. Attention was largely paid to the privatization of water services, which lent itself readily to the application of Marxist theoretical frameworks ${ }^{9}$. In this case, the political struggle was addressed as one pitting capital against water consumers. It dealt with the commodification of water without questioning the power relations embedded in the scientific discourse itself. Much attention was paid to local forms of water management and to the efficiency of communal property regimes ${ }^{10}$.. Many case studies were explored in depth through an actor based approach that sought to highlight how power relations manifest themselves in terms of the physical environment ${ }^{11}$. Yet, very little attention was paid to the social construction of water sciences and water technology within the politics of water management. Most social scientists respected the scientific 'facts' concerning water as an unquestioned evidence, as an objective reality to be accounted with. This was challenged somewhat within a historically limited focus linked to the construction and the impact of the European Water Framework Directive $^{12}$. Yet, minimum flow requirements, water quality indicators, biodiversity, sewage systems deserve more attention from this perspective. Why do we follow such requirements or indicators? Why do we resort to such technologies rather than to others? They may presently be put forward as neutral tools by those who promote them. Yet they systematically embody past compromises, past prioritisations that advantaged some actors over others and privileged some methods over others.

The lack of attention paid to the construction of the dominant water management narrative stems partly from the extraordinary difficulty involved in untangling the various mechanisms that produced it. The depth provided by a historical analysis over several centuries is priceless as it allows us to reconstruct the successive wars of position that led to paradigmatic reformulations of water management over time. Investigating infrastructure and its uses while harnessing historical methods to unravel the discursive constructions and the power relations that are embedded in it, is possible in the case of older canals where a wealth of yet unexploited archives allows us to shed light on the manner power relations and science have constructed each other over time. Such research serves the double purpose of illuminating a case study while allowing advances in the theoretical development of critical political ecology. This article, therefore, deploys a political science approach to study what is fundamentally a political problem: the construction of collective decisions concerning natural resources including their accompanying structures of legitimacy and domination. But this Environment and History 16.1 
study was made possible only through harnessing historical methods such as triangulating information from published work with the content of archives of the unpublished deliberations that led to those publications.

While French historians and political scientists have tended to exploit the archives of the state corps of engineers, we turned to the yet unexploited archives of non state actors, such as the 'Délibérations de la Chambre de Commerce de Toulouse' from 1802 to the beginning of the twentieth century. This allowed to reassess the construction of the scientific discourse concerning water and to reveal the crucial role played by non state actors since the early nineteenth century. It confirmed Forsyth's thesis, according to which the scientific discourse cannot be considered independently from the political struggle concerning natural resources. It nuances the dominant French narrative portraying water development as a state monopoly up to very recent times.

This article explores the case of the Neste Canal completed in 1862 in the South West of France to improve navigation on the tributaries of the Garonne, the third largest flow of all French rivers. It examines the mechanisms whereby both its use and the discursive construction accompanying it evolved over the last century and contribute today to justify the construction of the Charlas Dam. As this paper follows a political science approach, it doesn't provide a detailed chronology in the manner historians might have chosen to do. It discusses in depth the periods corresponding to turning points when the hegemonic concepts were shaped. It is based, however, on the comprehensive reading of the entire 'Registre des Délibérations de la Chambre de Commerce de Toulouse' meticulously kept throughout the nineteenth century once the chamber of commerce was re-established in 1802 following the French Revolution. It is also based on the comprehensive reading of the archives concerning the Neste Canal held at the Departmental Archives in Toulouse. This was completed with reading the archives of the Ponts et Chaussées concerning the Neste Canal.

Creating a water supply in the nineteenth century led to the construction of a water deficit in the twenty-first century. The advent of a $28 \mathrm{~km}$ long canal, with an initial flow of 2 cubic meters a second eventually generated the need for a 110 million cubic meters reservoir. Exploring the filiation of this infrastructure sheds light on the subtle manner supply management generates an ever increasing demand for water. These mechanisms lie in the paradigmatic formulation of the management issues. They stem from a discursive process deeply embedded in power relations. This article first explores the mechanisms that led to the construction of the Neste Canal in 1862. It then details the evolution of its insertion in the 
social and political constellation. Finally, it explores the manner in which this canal now participates in legitimising a large infrastructure project, the Charlas Dam.

The importance of state corps of engineers such as the Ponts et Chaussées have often led researchers to explore the archives of such corps when studying the development of French infrastructure. This may have contributed to a certain underestimation of the role played in this domain by actors other than the state. Picon, for example, reported that the French state benefited from the $18^{\text {th }}$ century onward from a quasi-monopoly in the domain of transportation infrastructure, including canals. ${ }^{13}$ Guillerme analysed the development of canals and roads by the Ponts et Chaussées as a reticulation policy designed by the state to control the entire territory. ${ }^{14}$ The case study explored in this article reveals the fundamental role played by an array of non-state actors in the development of the Neste Canal and other related infrastructure since its very origin in the early nineteenth century. Although we cannot generalise from one case study, the evidence provided by historical methods here lead us to question the usual portrayal of the development of water infrastructure in France as a typical Weberian bureaucratic process until the 1980s. Harnessing such an approach to study other case studies in France could reveal an overall history of water development that is much more complex and involves a great number of actors simultaneously competing to impose the scientific evidence and the technological solutions and to secure their control.

The use of the Neste Canal evolved over the last century, arguably, according to the actors who implemented these changes, on the basis of a productive logic. Archives and interviews of such actors allow the analysis of their narratives. This article locates their decisions and their positions within the social and political constellation in which they were functioning. This avoids writing a Whig history of the infrastructure, i.e. accounting for the past from the perspective of the present and portraying the successive constructions as technical solutions to objective needs. This approach allows us to identify three types of mechanisms participating in the construction of a water deficit now deemed to justify the construction of the Charlas dam. The first type of mechanism lies in the social construction of water science and technology. The second lies in the evolution of power relations among the state and other actors. The third lies in the insertion of the 'expert' within these power relations. These three types of mechanisms do not constitute an exhaustive list, but they provide an insight in the manner infrastructure seems to procreate independently from the users' and builders' will. They allow us to identify the successive paradigmatic shifts that now allow both the proponents and the opponents of dam construction to harness the environmental discourse. 


\section{The Neste Canal}

Undertaken by the French state in 1848, the Neste Canal became operable in 1863 (Figure 1). It carried water from a perennial tributary of the Garonne, the Neste River, in Sarrancolin, to the Lannemezan Plateau, where most of the Gascon water courses spring out. This transformed these intermittent tributaries of the Garonne into perennial streams.

This infrastructure was designed to include five technical components ${ }^{15}$ :

1- A navigable channel to carry water from Sarrancolin through the Lannemezan Plateau to a reservoir built at the top of the Save and Gers basins. Once on the plateau, this channel split into two branches, one of which reached up to the Baïse,

2- The Lannemezan Plateau reservoir

3- A canal that extended from the channel through the plateau to St-Martory

4- A canal that extended from St-Martory to Toulouse intended both for navigation and irrigation

5- The canalization of the Baïse River to improve its navigability.

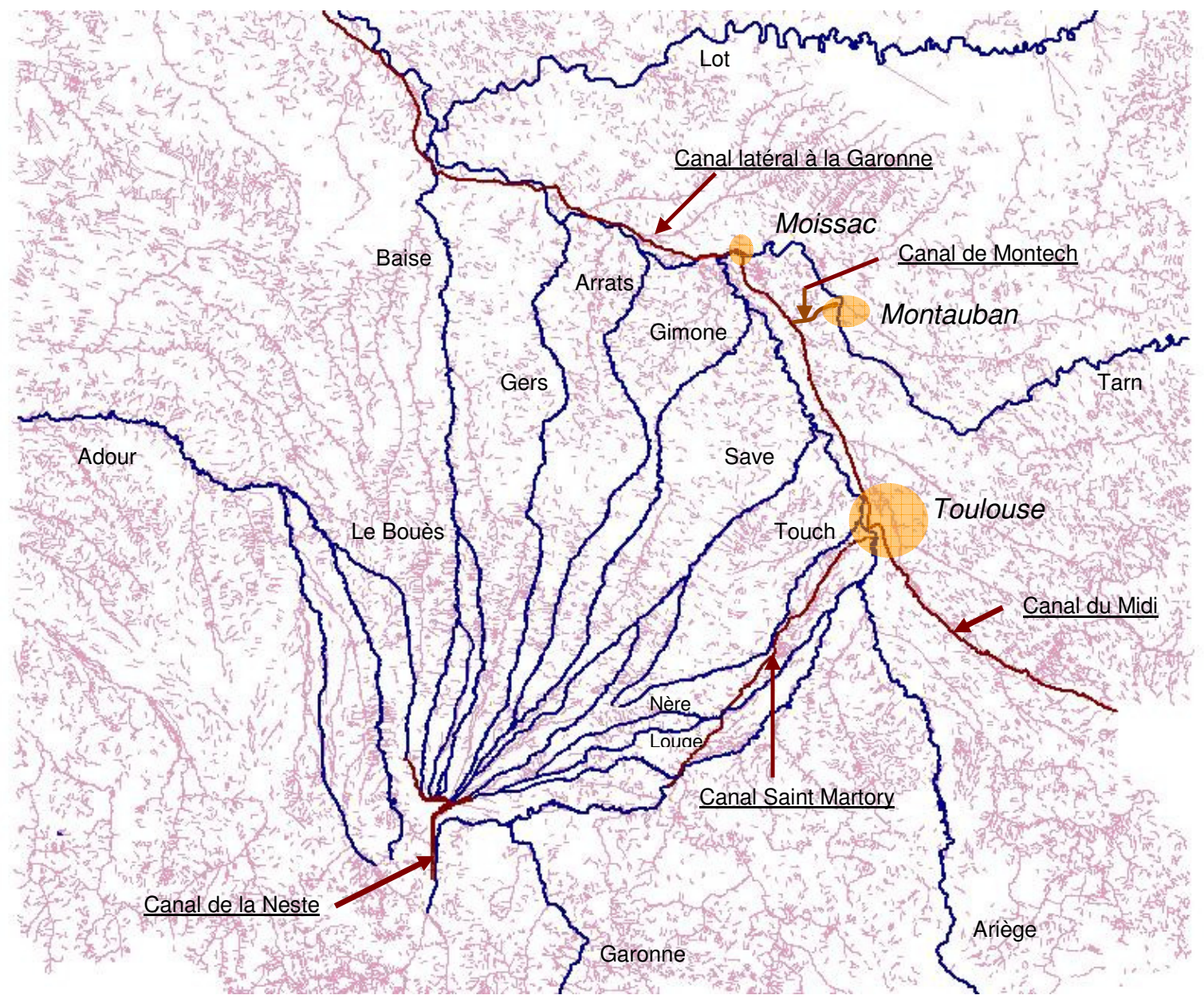

\section{Legend:}

Environment and History 16.1 


\section{- $\quad \underline{\text { Canal }}$}

- River

\section{Figure 1 : Map of a portion of the Garonne river watershed, including the main canals.}

The official Ponts et Chaussées project document written by Montet in 1841 claimed to pursue three goals:

"1- The establishment of navigable waterways that would be impossible without the recourse to foreign waters;

2- The irrigation of lands which the ardent southern sun burns every year;

3- The development of factories that are prevented from establishing themselves in southern secondary valleys because the seasonal disappearance of water would force them to stand still regularly",16.

Once operational in 1863, the canal carried 2 cubic meters of water per second, as opposed to the expected 7 cubic meters. In 1886, a decree ensured half of that flow must be set aside for a set of 8 navigable watercourses linked to the Baïse river. Indeed, the primary goal of the canal was navigation. Montet himself remains unequivocal about this in his project document: "The Canal that will bring the Pyrénées' water to the Garonne's plains, if it was only devoted to irrigation, would no doubt never be built; the state alone can undertake such a project and the state would not have undertaken it." ${ }^{\prime 1}$. The flow of the canal was later increased to seven cubic meters per second in 1909 and to 14 cubic meters per second in 1952, shortly before the creation of the Compagnie d'Aménagement des Coteaux de Gascogne (CACG). This corresponded to a change in the use of the infrastructure and to the progressive appearance of new actors.

In the 1950s, the state embarked on a national programme of improving irrigation through the development of water infrastructure ${ }^{18}$ It created sociétés d'économie mixte such as the CACG and granted them concessions for developing irrigation at the regional scale. The state policy of subsidizing 90 percent of the CACG's operational costs receded after 1972 and disappeared totally in 1991. Investments are still highly subsidized, although their overall volume has decreased. Crucially, the sources of funding have evolved as $95 \%$ are now channelled by Conseils Régionaux and Conseils Généraux, respectively regional and departmental elected 
bodies, rather than by the central state. A different set of considerations now determine the price of water and decisions concerning future investments.

A Whig history of the Neste Canal might portray this long evolution as a series of technical improvements, as a tale of progress and development. Yet, a careful scrutiny of the events reveals a harsh struggle at every stage among actors with competing goals and interests. While they systematically put forward arguments pertaining to a productive logic such as improving trade, agricultural production or environmental protection, their strategies were largely determined by a variety of other stakes. These are examined in the following section. The power struggles that determined the outcome of every decision along this path contributed to the changing relations among the various actors. These are analysed in the next section. These struggles also participated in the determination of what was expert knowledge and who was an expert. More crucially, they contributed to shaping the insertion of the "experts" within decision making mechanisms. This is analysed in the last section

\section{The social construction of water science and technology}

Science and technology are a political and social construct. Theories and techniques never become dominant because they were objectively the most logical or the most accurate. They rise to hegemonic status when the social groups that promote them become dominant ${ }^{19}$. Any understanding of the 'development of water' must entail the exploration of the mechanisms whereby water sciences, technologies and management were constructed. The history of the Neste Canal reveals the links between the original rationale for the construction of the canal, the development of irrigation, the sudden increase in maize production, the development of the minimum flow requirement as the crucial environmental indicator, and the present construction of the inevitability of the Charlas dam. The social and political struggles over each of these issues led to a series of paradigmatic reframing that eventually showed the construction of a dam as the only solution to cater for a derived demand for water. In other words, science and technology were largely constructed by social and political power relations. Yet, conversely, the present scientific discourse and technology largely limits the power struggles that can now take place.

\section{The origins of the Neste Canal}

M. Montet, chief engineer of the Ponts et Chaussées at the ministry of infrastructure, designed the present Neste Canal. His project aimed to "detain those waters of the Neste that exceed the Environment and History 16.1 
needs of its shores and flow by, wasted for all, and bring them on the Lannemezan Plateau in order to distribute them, at an opportune time, over all of the sub Pyrenean region where their need is felt for navigation, for irrigation and for the movement of industry." ${ }^{20}$. The state funded this construction. To the Chambre de Commerce of Toulouse (CCT), this represented the first concrete step turning a forty year old project into reality.

Established on 24 December 1802, following the law that recreated the Chambres de Commerce in France's bigger cities after the revolution, the Chambre de Commerce of Toulouse devoted its efforts preponderantly to the issues of canals over the course of its first year of existence. It protested vehemently to the Ministry of Interior against the proposal made by the mayors of Moissac and Montauban to build a canal extending from Toulouse to Moissac. ${ }^{21}$. It published a mémoire in 300 copies arguing that the Garonne was absolutely navigable between Toulouse and Moissac,that only minor works needed to be carried out on its banks to maximise the safety of the ships travelling along its course. The mémoire insists on a productive logic within its arguments: two thirds of the shipwrecks occur between Moissac and Bordeaux, the cost of shipping would become prohibitive on such a canal, and most of the shipwrecks between Toulouse and Moissac are due to collisions with floating mills that can be removed by virtue of an unenforced law ${ }^{22}$. They contend that the proposed canal would be both useless and extremely expensive for the public treasury. They add that the project of a canal linking Bayonne to Toulouse would be extremely beneficial as it would allow communication with Spain.

While the arguments above all reflect a productive logic based on sound scientific evidence, a strategic logic emerges from the unpublished deliberations of the CCT. Comparing this logic with the one that was officially put forward within the CCT's publications allows to better appreciate why certain scientific facts were considered rather than others. The Canal du Midi had been completed from Toulouse to the Mediterranean harbour of Sète by 1681. Toulouse then developed an advantageous commercial position as a necessary warehouse where the larger boats travelling on the Canal du Midi must discharge their goods before they were loaded onto smaller embarkations capable of travelling on the Garonne River. The CCT aimed first and foremost to maintain this advantageous position for Toulouse. Extending the canal to another city or town would have caused the entire shipping and warehouse industry to move there. Such a project, which would be based on the observation that the Garonne was not navigable, threatened deeply the Toulousan economy. Determining the navigability of the Garonne River was, therefore, a politically laden issue. Simultaneously, Toulouse wanted an extension of the Canal du Midi that would reach Bayonne. This would allow for trade routes Environment and History 16.1 
that avoided Bordeaux, Moissac and Montauban altogether, a prospect that could only please Toulouse merchants.

While the CCT members write their concerns explicitly in the confidential minutes of their meetings, they usually prefer brandishing scientific arguments that will oppose scientific evidence to their opponents when they face actors threatening their privileged position. This leads the CCT to privilege some measurements and observations over others. This approach appears explicitly in 1821, when the CCT insists on two points. First, it lobbies for the extension of the proposed canal to the confluence of the Tarn and the Garonne instead of to Montauban to prevent its replacing Toulouse as the "warehouse of the Canal du Midi". Second, it insists that the proposed canal be a class 2 canal, cheaper, smaller and only capable of accommodating embarkations that could travel on the Garonne. As it wouldn't accommodate the larger boats that travelled on the Canal du Midi, Toulouse could keep playing its crucial warehouse role in the transport between the Mediterranean Sea and the Atlantic Ocean ${ }^{23}$. It would remain the home of a thriving shipping industry.

The navigability of the Garonne River, supposedly an objective, neutral measurement of a technological possibility, was highly disputed between Moissac, Montauban and Toulouse for commercial reasons. The 'blackboxing' of a scientific claim refers to the collective process that transforms it into an unquestioned scientific fact ${ }^{24}$. The 'blackboxing' of the Garonne's navigability was a harsh struggle that extended over several decades. It officially pitted statistics and scientific observations against each other. But these were formulated to suit the interests of specific parties ${ }^{25}$. The CCT lost a first round as the Conseil d'Etat approved the construction of the lateral canal in 1832. But it won in the long term when it succeeded in obtaining that this canal be only a class 2 canal.

The struggle to avoid the construction of the canal to Moissac was enmeshed with a concurrent one to "complete the Canal of the Two Seas". Riquet's initial idea was to link the Mediterranean Sea to the Atlantic Ocean. The CCT championed extending the Canal du Midi from Toulouse to Bayonne. In its 1808 meeting with Emperor Napoleon, this was its only request. Portraying that stretch of land as extremely fertile, they told Napoleon that "This canal would create men and wealth that will never exist without it, the imperial navy could benefit from the best masts and the best construction wood...,26 They expected a cost of 20 millions 'only' which triggered Napoleon's enquiry whether the revenue of the canal would amount to 300000 franks. The members of the Chambre de Commerce answered an unambiguous "yes", but took care to mention in their record of this meeting that the canal would bring about an increase in the activities that would eventually allow the generation of Environment and History 16.1 
such revenue. Such certainties on the part of the Chambre de Commerce members concerning the project costs, and more generally its finalised status, surprises for. Indeed, only two months earlier, they were writing to the Préfet of the Gers asking whether he could search his office for the blueprints concerning the canal to Bayonne that had been established in 1785 by Messire de La Chapelle. ${ }^{27}$ The Préfet had been unable to locate the documents. ${ }^{28}$

The systematic reference to a Canal of the Two Seas instead of to a Toulouse Bayonne Canal is part of a construction of inevitability that is essential for the advent of any infrastructure ${ }^{29}$. In this case, it portrays the Canal du Midi as an incomplete project. The CCT systematically cultivated the memory of Riquet to recall its version of his initial goal. It achieved this in a variety of ways such as the ceremony it held to mark the reception of Riquet's medal on 29 April $1827^{30}$.

Once Galabert, a free lance, seat of the pants engineer who was neither a member of the state corps or a graduate of a civil engineering school, published in 1830 the project of a canal that would take its source in the Neste, carry water both along the Pyrénées up to the Bec du Gave, near Bayonne, and to Toulouse, the CCT became his keenest ally. It wrote to the Minister of Interior that this canal would create immense wealth, noting that "via easy irrigation, arid plains would be transformed into fresh and rich meadows, the product of which are less sensitive than others to the vagrancies of the climate." ${ }^{31}$. When Galabert, who had by then managed to be elected as deputy of the Gers, informed the CCT of the Conseil d'Etat's decision to approve the lateral canal, the CCT sent him 600 copies of its 1831 mémoire to distribute to the legislative assembly, and rallied many other chambers of commerce to its efforts. Clear alliances emerged between actors pursuing very different goals, but sharing an interest in a specific definition of the Garonne's navigability and in the construction of a canal from Toulouse to Bayonne ${ }^{32,}$. These alliances allowed a specific "scientific" discourse to prevail concerning these issues.

Galabert died in 1841, ruined by his ambitious, failed project. So when the CCT examined Montet's project of a Neste canal the same year, it perceived it as a partial fulfilment of Galabert's project, a subsidized first section of the canal to Bayonne. In his report on this new project, Arnoux notes "If Galabert's canal was to be executed in its entirety by speculators, the navigation tax would be sizeable, these taxes would be based on the importance of the capital invested in its construction; the taxes would need to cover the interest payments of that capital, but would also need to cover the maintenance and the operation costs. The portion that the government will build cannot cause an expensive tax because the State must not speculate." 33 The Chambre de Commerce perceives this project as a subsidized first section of Environment and History 16.1 
the canal to Bayonne it has wanted for so long. The project became even more attractive once the Chemins de Fer du Midi, a private railroad company, acquired a concession on the canal lateral in 1852 and a lease on the Canal du Midi in $1858^{34}$. It practiced a tarification for navigation on these channels that was competitive with rail transport. The CCT fought this tarification for decades, arguing that the low added value of the area's products, maize and timber essentially, meant that this high transport cost was prohibitive to their exportation ${ }^{35}$. Improving navigation on the Baïse, where no tariff could be exercised because it was a natural water course became even more attractive to the CCT. The Neste Canal was thus not only a first step in the realisation of the Toulouse-Bayonne Canal, it was also useful in the short-term because it could supply the Baise river system with a permanent flow of water that would allow navigation and therefore avoid the unacceptable tariffs levied on the canals.

While the proponents of the Neste Canal were only concerned with navigation, they harnessed irrigation to further their cause. "Over one hundred thousand hectares of land desiccated by the rays of a scorching sun will receive the fertilizing water of the Garonne. This water, carried to the top of hills, will transform our arid plains into rich pastures. Then, butcher's meat, the expense of which presently deprives the labouring class from a food so necessary to the sustenance of physical forces, will certainly decrease in price. Cattle, that is lacking to the work of the ploughman, will multiply in the great properties..." ${ }^{36}$. Yet, Montet was unequivocal about the irrelevance of irrigation to his project. Still, the discourse on irrigation was reiterated for decades and later largely shaped the narrative of water management in the area. It allowed portraying the canal as serving the public good.

The construction of the Neste Canal resulted from a combination of commercial interests that led the merchants of Toulouse to strive to preserve their advantage acquired in 1681 over Montauban and Moissac by championing the extension of the Canal du Midi to Bayonne. This process included the blackboxing of the navigability of the Garonne River in order to defeat the project of the Lateral Canal to Moissac or Montauban and their allying with Louis Galabert when he undertook the vast project of the Canal des Pyrénées as a private venture he attempted to fund via private subscriptions. Throughout the nineteenth century, proponents of canals systematically added to their pile of arguments the value of their projects for irrigation over thousands of hectares, claiming the fertility of land without either studying it, surveying the area involved or even consulting the farmers. This contrasted with their elaborate calculations of infrastructure costs and ensuing navigation taxes compared with the costs of transport by rail. 
Corps such as the Ponts et Chaussées started developing profitability or efficiency calculations to judge the opportunity of infrastructure projects in the second half of the $18^{\text {th }}$ century. They held that they appropriated the values of public utility, universality and impartiality. ${ }^{37}$ Calculating the utility of a project therefore served to demonstrate their rectitude, in principle. The evidence provided by the archives shows that they chose the numbers rather arbitrarily to support their values. The construction process through the nineteenth century produced the infrastructure of the Neste Canal as well as a series of blackboxed 'scientific facts'. These included the issue of navigability and irrigation. This discursive process erected irrigation as a necessary development that would enrich the area. Yet, this discourse was constructed entirely by social actors who neither practiced nor invested in irrigation.

\section{The emergence of irrigation}

While a specific configuration of power relations in the nineteenth century, structured essentially around the stakes of trade and navigation, produced the infrastructure of the Neste Canal and a discourse promoting irrigation, other mechanisms explain the advent of the practice of irrigation itself. These include the interventionist approach of the French state after the Second World War to promote irrigation and maize cultivation, but they also include international influences via the Marshall Plan and the Common Agricultural Policy of the European Union. A set of power relations led irrigated maize to become the predominant factor in the construction of a water deficit that now justifies the Charlas Dam.

\section{Maize in the South West of France}

Introduced in the South West of France from Spain in the $15^{\text {th }}$ century, maize long appeared as a suspicious plant reserved for animal feed because of its reputation for spreading diseases. Yet, more resistant than other crops, it could feed humans in time of crisis. ${ }^{38}$ At the time when the Chambre de Commerce de Toulouse strives actively to obtain a navigation canal to Bayonne, it also successively reports excess of maize for which no demand exists in France. In 1803, it asks permission from the Ministry of Interior to sell this maize in Spain and Corsica, explaining that the crop was very good but no one in France wants to buy such a product, so maize "rots" in the granaries. ${ }^{39}$ It renews such a request a year later for identical reasons. $^{40}$

The overall improvement in productivity in agriculture throughout the nineteenth century reduced the importance of maize as the 'insurance policy' in case other crops failed. Its Environment and History 16.1 
production dropped steadily in France, from 600,000 cultivated hectares in 1840 to 300,000 hectares in the 1930s. By 1900, maize was increasingly imported from French colonies such as Madagascar and Indochina. In 1930, the Compagnie de Chemins de Fer du Sud-Ouest organised the first international conference on maize in Pau hoping an increased production would fuel a demand for its service ${ }^{41}$. The fact a railroad company convened this conference highlights the inexistence of any organised community of maize growers. The Association Générale des Producteurs de Maïs (AGPM) emerged in 1934 largely as a result of the Pau conference.

The Marshall Plan, the Food and Agricultural Organization (FAO) and the United Nations Reconstruction and Recovery Administration (UNRRA) introduced hybrid varieties of maize in France, following the Second World War, allowing higher productivity per hectare ${ }^{42}$. The USA aimed essentially to balance its accounts and wasn't so much aiming to make French agriculture dependent on American seeds as it was trying to transform it into an export sector that could fund imports from American industries. French farmers resisted adopting American hybrid maize because such seeds only produce one crop of high yield cereals. Farmers must buy seeds again for the next crop. Such dependence clashed with the traditional practices of French peasantry ${ }^{43}$.

The French state reacted quickly to this sudden intrusion of American hybrids. It created the Institut National de Recherche Agronomique (INRA) (not defined earlier, spell out in full here) in 1946 to develop agricultural productivity, notably by developing its own brands of maize hybrids. The INRA 244 and 258 were thus developed with three goals in mind: producing species that would be stable and distinct in order to allow anti-fraud control and an intellectual property regime, producing homogeneous species to allow for mechanisation and producing species that reacted well to fertilisers and pesticides. ${ }^{44}$ A public establishment, the INRA worked hand in hand with private seed suppliers and with activist movements such as the Jeunesse Agricole Catholique, represented in the Centre National des Jeunes Agricultueurs (CNJA), an influential group within the Fédération Nationale des Syndicats d'Exploitants Agricoles (FNSEA), in order to change the identity of the French peasantry so it would perceive itself as belonging to a technical profession. This was part and parcel of the Gaullist effort to modernise agriculture and free manpower to enter industry and the services. It was necessary to persuade farmers to adopt hybrid maize they didn't want. It also had unforeseen consequences on the balance of power between state and professional organizations which will be explored in the second part of this article. It eventually empowered farmer associations such as the AGPM. 
After coercing and persuading French farmers to cultivate new crops such as hybrid maize, the French state persuaded them to irrigate to improve productivity. The discourse, elaborated since the beginning of the nineteenth century, according to which irrigation would enrich the area, had become unquestioned by the 1950s, even though it had only been produced as a justification to attain other goals.

The massive cultivation of maize in the South West of France induced a derived demand for water, i.e one in which the need for a factor in production derives from the need for the final product this factor helps to produce. The focus was placed on the demand for water without questioning the construction of the demand for the product this water was producing. When irrigating maize was criticised at the beginning of the $21^{\text {st }}$ century, the soaring oil prices spurred a new discourse. Biofuel produced from maize would contribute to curb global warming.

\section{The advent of the minimum flow requirement}

The concept of a minimum flow requirement, now blackboxed, plays a crucial role in the filiation process linking the Neste Canal and the Charlas Dam. Initially an anthropocentric idea, the minimum flow requirement eventually became the crucial environmental indicator harnessed to justify constructing the dam.

Montet's project detailed an anthropocentric definition of the minimum flow requirement ${ }^{45}$. Only those waters of the Neste that are superfluous to the present and future needs of its shores are to be deviated ${ }^{46}$. These needs clearly did not include the environment. Yet, this minimum flow requirement was eventually going to become the pivotal environmental indicator for water courses. Over the next century and a half, it was to acquire an ecocentric character absent from its initial formulation. The Water Management Master Scheme officially adopted by the Adour-Garonne Basin in 1996 for a period of validity lasting until 2009, adopted the following definition 'The minimum flow requirement is the flow value determined by the Water Management Master Scheme:

- above which the normal co-existence of all uses and the healthy function of the aquatic environment are guaranteed,

- which must thus be guaranteed every year during the low water period, with tolerances defined in table $\mathrm{c}^{, 47}$

The construction of water indicators shows three phases. The identification of a characteristic is first generated by the use of the resource ${ }^{48}$. In the Neste case, the capacity of a watercourse to allow navigation was defined in 1841 as the most important characteristic; ie its flow. As 
the watercourses of the plateau were intermittent, the second phase of the construction of the indicator, the measurement of that property, could only consist of setting an artificial target to be reached thanks to infrastructure that would alter the natural flow. This occurred because a set of actors with specific interests were producing these definitions. Finally, the third phase of indicator construction, the transformation of this measured property into a variable within a model, was achieved by those who managed the infrastructure. Once an indicator is established within a predominant discourse, its users forget the specific options that generated it in the first place ${ }^{49}$. This certainly was the fate of the minimum flow requirement in the river system fed by the Neste Canal.

The 1984 law set minimum flow requirements within rivers and downstream of dams to at least one tenth of the average yearly flow. The minimum flow requirement became the basic environmental indicator for a watercourse. As the watercourses of the Lannemezan Plateau are intermittent, setting a minimum flow requirement entailed the construction and maintenance of reservoirs. Since 1979, the overall use of water over the entire basin has decreased but the irrigation of maize has increased the withdrawal at the time of low water ${ }^{50}$. The problem is not defined as an overall lack of water but rather as a problematic seasonal distribution, so a dam offers the ideal solution to alter this distribution. Respecting the environmental discourse and respecting the irrigation demand now apparently converge in requesting the construction of more dams. Initially, these appeared to satisfy sectoral interests, such as irrigation or power generation. The advent of the minimum flow requirement as the crucial environmental indicator allowed the emergence of ecological dam construction. A wide ranging set of actors could all harness the environmental discourse as it matched their interests. By advocating the respect of the minimum flow requirement, farmers could request the Charlas Dam to protect the environment and, incidentally, supply the additional water required at peak times, dam builders could claim to build dams in order to protect the environment, and the state could justify building a tool that maintained some control in its hands within the post-1981 decentralization era. Such a rallying around the environmental discourse has been observed elsewhere, in developing countries where attention was more readily paid to the multitude of actors, apart from the state, that determine the management of environmental resources ${ }^{51}$. The Neste case demonstrates such a phenomenon also occurs in industrialized countries.

The Scientific Council advising the Comite de Bassin Adour-Garonne questioned the validity of the minimum flow requirement as the essential environmental indicator in 1998. It failed to reopen this black box, however. Such were the clash of interests between this scientific Environment and History 16.1 
enquiry concerning the best environmental health indicator and the actors who relied on the hegemony of the minimum flow requirement to further their strategies that the Comité ceased to take advice from the Scientific Council. Closure was reached and the concept of the minimum flow requirement was black boxed for the next foreseeable future. This constituted an important step in the construction of inevitability of the Charlas Dam.

\section{Paradigmatic reformulations}

While the project of the Charlas Dam exists since the 1970s, when the French state required the CACG to identify all the potential dam sites, this project cannot be portrayed as a simple state initiative. It was produced by a series of paradigmatic reformulations that linked inexorably the construction of the Neste Canal with that of the Charlas Dam. Interestingly enough, the state did not appear as a leading actor within any of these paradigmatic reformulations. First, the rivalry between the merchants of Toulouse and those of Moissac and Montauban led to the construction of the Neste Canal and its portrayal as serving the public interest. This process was closely enmeshed with the definition of the navigability of the Garonne River. The reformulation of the merchants' interests into a requirement of infrastructure serving the public interest entailed the propagation of a discourse portraying irrigation as serving public interest. This paradigmatic reformulation produced the minimum flow requirement initially as an anthropocentric concept. The discourse on the civilizing power of irrigation was reproduced for a century before the state actually intervened actively, via the creation of the CACG, to bring irrigation water to the farmers' plots in spite of them and free of charge.

Each of these paradigmatic reformulations of particular interests into public interests and afferent infrastructure needs was accompanied with a concomitant scientific construction: the navigability of a river in one case and the minimum flow requirement in the other. The latter was reformulated in the twentieth century as an ecocentric concept and harnessed within the environmentalist discourse. These reformulations, where technology and science have contributed to each other's construction, constitute the first type of filiation mechanisms linking the Neste Canal and the Charlas Dam. Indeed, once a discourse had become hegemonic, for example, once all actors needed to justify their strategy as furthering the necessary development of irrigation, or furthering the necessary protection of the aquatic environment, their degree of freedom was consequently constrained by this discourse.

\section{The evolution of power relations among the state and other actors}


Traditionally, French studies of public policy integrated the Weberian hypothesis of a state bureaucracy formulating top down policies and implementing them through sectorial departments. The French water law of 3 January 1992 set up an optional participation of a set of actors in the elaboration of water policies. It called for 'concertation', a participatory process, via Commissions Locales de l'Eau (CLE) as the institution in charge of elaborating a Schéma d'Aménagement et de Gestion de l'Eau within a basin (SAGE). This led to a reconsideration of this state centric approach, but only to examine the period following the decentralisation act of 1981 and the water act of $1992^{52}$. Yet, the state was not an initiator of infrastructure policies through the nineteenth and early twentieth centuries. It reacted to private sector initiatives which led it to experiment with private public partnerships institutionalised as companies before the Second World War ${ }^{53}$. The first section of this article demonstrated that the Weberian hypothesis of a top down formulation of state policies concerning water certainly does not apply through the nineteenth and twentieth centuries within our case study. Both the decisions to build infrastructure, the Neste Canal and its accompanying reservoirs, and the accompanying discourses to legitimise and change its uses, resulted from a great variety of competitions and co-operations among a set of actors active over widely differing scalar levels. The state appears in this narrative only as a powerful actor among many. It wasn't the initiator either of the discourses or of the infrastructure plans in the nineteenth century. It posed as the driver of social engineering to transform a peasant society into an entrepreneurial agricultural society after the Second World War. But it did so very much as a reaction to external decisions, such as those made by the United States within the Marshall Plan, and within the narrow rails constructed by the discourse that emerged as part and parcel of the infrastructure in the nineteenth and early twentieth century. Furthermore, the "new approach" announced by the 1991 law is one of "concertation", a participatory process, as opposed to negotiation. It postulates the existence of an objective public good that will be reached if actors discuss sufficiently. It ignores the fact that the definition of a public good is a discursive construction that results from the strategies of heterogeneous actors once they emerge as dominant. The idea of irrigation furthering the public interest of the south west of France is a stark illustration of this as was detailed in the first section of this article.

The weakness of post-colonial states probably eased the identification of such actor struggles within natural resources management in the developing world. Migdal detailed the complex compromises developing states had to reach with the many actors exercising social control within their borders ${ }^{54}$. The study of the interaction between such power relations within human societies and the environment eventually came to be recognized as political ecology ${ }^{55}$. Environment and History 16.1 
This approach focussed on deciphering the power struggles and their accompanying discursive constructions in order to shed light on the manner societies interacted with their environment $^{56}$. Significantly, such approaches were initially only used to study developing states $^{57}$. In Europe, the Weberian hypothesis largely prevailed and prevented inductive approaches rooted in field observations, interviews and archival work such as is presented in the first section of this article. Instead, a deductive approach privileged the study of water laws and portrayed public policies largely as top down developments ${ }^{58}$.

Regionalism and decentralisation were often shown as succeeding a period of state dominance and the regal character of the French administration was shown as an impediment to the "concertation" mechanisms it was attempting to deploy". Yet, the theoretical body produced by studies of cases in developing countries proves very useful to understand the Neste situation.

The nineteenth century saw a fierce battle pitting the engineers of the Ponts et Chaussées and independent entrepreneurs such as Galabert to secure a monopoly over large infrastructure projects. When the author of the corps' report on the Neste Canal project recalls all of the Ingénieurs en chef who, before Galabert, offered another path for the channel, he is constructing the inevitability of both his own project and his corps securing that monopoly ${ }^{60}$. The state limited riparian rights in 1919 and instituted a regime of concession or authorization for producing hydroelectricity. The state was thus reacting to private hydropower development and was trying to gain control over it.

Dams were built in the Pyrénées at the end of the nineteenth century, upstream from the Neste, affecting the supply of the Neste Canal. Once irrigation developed, the schedule of water release became crucial. Irrigating farmers didn't usually need water at the times most appropriate for electricity generation. In 1957, Electricité de France (EDF), the national electric company, negotiated schedules of water releases for the Neste system with the Ministry of Agriculture. Once created, the CACG took over this negotiation role. In 1960, the state granted the CACG a concession on a series of dams and irrigation perimeters it was due to build. In 1963, the state allocated the CACG 48 million cubic meters of water at will from EDF dams, to distribute free of charge. Between 1972 and 1991, The CACG started selling water to cover its high fixed costs. It gains from selling ever more water to the farmers and would face bankruptcy if the sales dropped excessively. The state had initially created the CACG as its instrument, but by 1991, it had become a relatively independent actor with its own stakes and strategies concerning water management in the Neste system. It had forged 
new alliances with regional and departmental councils, elected public bodies with local authority, the power of which increased progressively following the 1981 decentralisation act. Irrigation strengthened the AGPM and the various Chambres d'Agricultures that became powerful professional associations. Their role now resembles that played by the CCT in the nineteenth century. They show no resemblance with the Société d'Agriculture of the nineteenth century that strove to educate "backward locals". The 1964 water law set up Comités de Bassin and Agences Financières de Bassin throughout France. The 1992 water law required them to develop water management schemes on the basis of concertation with all stakeholders.

The Neste Canal has existed within a hydropolitical constellation that includes a vast array of actors deploying strategies over very different scalar levels. These actors evolved over time. New ones appeared and others lost their power. But at no time, was the state a monolithic or monopolistic actor determining the fate of water management. The changing power relations among these actors determined the construction of the management objectives. Initially, water was carried to allow navigation and civilizing 'backward' areas. This objective changed into growing maize to export and generate foreign currency. Later, water had to be supplied so that the CACG could remain in business. Now, it is being channelled so that biofuels will curb global warming. The changing power relations largely determined the place environment occupied within these decisions, the manner problems were perceived and technical solutions conceived. Throughout, laws and decrees issued by the state appeared reactively, as tools of the state, never as driving forces bringing about fundamental change.

\section{The Insertion of the Expert within decision making processes}

Throughout the filiation process whereby the Neste Canal spawned the Charlas Dam, "expert knowledge" played a significant role. Few individuals were recognized to have the capacity to define either public interest, the navigability of the Garonne, a correct indicator for environmental health, the best technological choices, the most efficient agricultural practices, or the most appropriate crops. Those who benefited from such recognition will be referred to here as "the experts". The first section of this article showed how these issues were shaped by numerous power struggles enmeshed with each other over various scales. The second section detailed how new actors emerged on the scene as time went by and how the power relations among them evolved. Each actor tried to identify "its" experts to put forward a rational and scientific case in line with its own strategy. The mechanisms whereby experts are embedded within these power relations and these decision making mechanisms is worth examining. It 
contributed largely to determine what constituted acceptable, reliable knowledge, what constituted progress and development. These mechanisms explain why completely valid knowledge was silenced throughout the two centuries of this process. What factors legitimise knowledge as valid both in the experts' eyes and in the eyes of those who listen to them, what power is granted to the experts, who pays them, which formal and informal networks they belong to, such as, in France, the alumni associations of the "higher schools", the corps, all contribute to determine the mechanisms whereby experts are embedded within power relations and decision making within this process.

The advent of modernity has been described as a specific alliance between the "experts" and the state apparatus that emerged between the $17^{\text {th }}$ and $19^{\text {th }}$ century in Western Europe when the ruling class progressively changed its role. "Nothing less was required than the acceptance of state expertise in the art of living; it had to be admitted that the state and the specialists it appointed and legitimized knew better what was good for the subjects, and how they should live their lives and beware of acting in a fashion harmful to themselves. The subjects were not only denied the ability to find their way to God; they were denied the capacity of living human life without the surveillance, assistance and corrective intervention of those in the know." ${ }^{\prime \prime}$. This power knowledge syndrome constitutes the most conspicuous aspect of modernity.

By the time Napoléon broke openly with the "ideologists" in 1812, the major engineering schools had already been created as institutions of the French state. The Ecole Nationale des Ponts et Chaussées alone stemmed back to the old, monarchist regime. The Ecole des Mines and the Polytechnique emerged during the revolution. The 1812 divorce between the French state and the experts only involved the social sciences. The natural sciences had been structured firmly as a branch of the state apparatus. Engineers spent their professional lives in either private enterprises or government departments but belonged to "corps" issued from their schools. This specific structure within "corps" is part of what led Jean-Jacques Pérennes to study "the engineers" as a specific class of social actors within the development of water ${ }^{62}$. The corps ensured a certain homogeneity in the societal options the members adhered to.

The modern view of the world postulates the existence of universally applicable principles governing both the physical and the social world. The post-modern watershed, that transformed social sciences in the last thirty years, has scarcely penetrated the natural sciences and the engineering world. This results both from the incompatibility of the theoretical frameworks and from the alliance between these engineering schools and the state apparatuses. Modernity and post-modernity are two sharply different contexts, that can coEnvironment and History 16.1 
exist, in which the intellectual role is performed ${ }^{63}$. This is shaping both the experts' knowledge and their means to transmit this knowledge as valid. This is participating in the filiation process linking the Neste Canal and the Charlas Dam because it is contributing to the labelling of knowledge as valid and to its being articulated within infrastructure decisions.

The experts are not necessarily produced within the "Higher Schools", however. While the state used the CCT throughout the nineteenth century as a reservoir of experts on economic issues, it only used the Société d'agriculture as a tool to civilise the backward peasants of the area. The study published in 1891 by the CCT specifies outright the claim to legitimacy of its author: he has, it claims, the practical sense of a merchant who knows how to draw on his own professional experience in order to establish, through rational deductions, an excellent defence of public interest ${ }^{64}$. Legitimizing knowledge by invoking its being grounded in rationality is typical of modernity. Yet, this statement reveals the social hermeneutics at work because it links the attribution of rationality to the social status of the author: a successful merchant, i.e a member of the notability.

Conversely, the Société d'Agriculture was not headed by peasants, but by "experts" such as professors of agriculture at the University of Toulouse, physicians and senators. Its yearly reports to the préfet, from 1864 on, detail well the insertion of experts within society. It received books from the ministry of agriculture to teach the local peasants good agricultural practices. It held annual contests to reward those deploying "best practices". The plowing contest was especially used to demonstrate the benefits of mechanization ${ }^{65}$. In 1894 , the President of the Agricultural Societe of the Haute-Garonne, also professor at the University of Toulouse, travelled to a conference at Oxford to learn from other detainers of recognized knowledge grounded in "rationality". Yet, he doesn't seem to have ever visited Prades, in the Oriental Pyrénées, where he could have learned century old irrigation practices ${ }^{66}$. The knowledge and experience developed by the Prade peasants could not be ascribed to rationality because of their social status. It seemed preferable to count on Oxford experts to learn about irrigation in the South of France.

The opinion voiced by the experts concerning the peasants they were supposed to civilise appears clearly in the nineteenth century documents. In 1840, a mémoire from the Ponts et Chaussées defends the project of the Neste Canal thus:

"[...]we would soon see the moors that still cover it converted into rich and fertile plains; and its population, rare and in a state of first nature, so to say, grow and rise, through its contact with the more advanced populations, to the same level of civilization as the rest of France." 67 Environment and History 16.1 
Such a paradigmatic definition of valid knowledge prevented the recognized experts from acquiring any knowledge from the peasants in the area. Thus, when the municipal councils of these "backward" villages reacted in 1901 to plans for a new regulation of the pricing of irrigation water, their observations were not taken into account. Their objections covered the flow of water necessary to irrigate one hectare, the irrigation calendar, the proposed price of water compared to the monetary yield per hectare, the poverty of the local soil, its being water logged in the spring, which renders irrigation useless for hay production. All such observations were drawn from their professional experience on the basis of rational deductions. But their social status prevented any recognition of that rationality.

Experts were never entirely embedded within state structures, either. Galabert was not a member of any corps, but his project very much informed that of Montet. Experts seem to have been most deeply embedded in state apparatuses during the three decades following the Second World War, when water was brought to the farmers by the CACG in 1952 free of charge because they didn't want it. Even then, the ministry within which an expert was embedded would greatly determine whether his scientific claim would eventually be transformed into a scientific fact. Experts could rely on their informal networks to cut across ministerial compartmentalization but this remained an arduous task.

The decentralization act of 1981 and the Water Act of 1992 led to the creation of new institutions that also hire engineers either directly or via the recourse to consultant firms. The manner in which experts are now embedded has thus been altered. Their legitimacy to coerce lesser beings in accepting the consequences of their judgement was grounded in their purported ability to define the public interest. Now that experts are working for regional or departmental bodies instead of national ones, their claim to formulate the public interest is being eroded. Most of them subscribe to a paradigm steeped in modernity and adhere wholeheartedly to principles they deem to have universal applicability. But their employers may not share their vision altogether.

The experts played a key role in the filiation process between the Neste Canal and the Charlas Dam. They served to legitimize the knowledge that was put forward within a productive logic. Who was recognized as an expert, however, depended on social processes that prevented much knowledge from being harnessed. Who hired the expert, on the other hand, largely determined the resonance of his scientific claim. The fate of the scientific council which used to advise the Comité de Bassin Adour-Garonne illustrates this starkly.

The soaring oil prices until the middle of 2008 have created a new rapprochement among some of the experts. The fuel produced from maize became competitive with petrol. This Environment and History 16.1 
brought about an increase in the price of maize on the world market. In 2007, maize irrigating farmers generated profit even without EU subsidies and thus express an increased demand for water. The ecologists concerned with climate change approve the replacement of fossil fuel with one that generates a new carbon sink with the next crop. The CACG can only approve all this as its viability depends on the quantity of water it supplies. Construction firms can now claim the dams they build not only maintain the minimum flow requirement necessary to preserve the local ecosystem, they now also allow solving the biggest environmental problem at the global scale: climate change. This convergence of interests among the actors in which experts are now embedded is contributing to the promotion of a specific technology, biofuel, and to the silencing of other technologies such as the hydrogen fuel cell. These technologies are not being compared on the basis of their relative merits and demerits. The scientific discourse is harnessed by actors who have specific stakes in the promotion of a certain technology or scientific claim. This occurred for the definition of the navigability of the Garonne in the nineteenth century, which eventually allowed the construction of the Neste Canal. It is now occurring for the promotion of biofuel, which is now the strongest argument supporting the construction of the Charlas Dam. As the basin only consumes $60 \%$ of its renewable water resources over the course of a year, dams allow the summer consumption necessary to grow maize.

\section{CONCLUSION}

Do canals spawn dams? They seem to do so in subtle ways. Their material construction is necessarily accompanied by that of a scientific discourse that blackboxes facts and technologies. These hegemonic concepts arise thanks to wars of position, in the Gramscian sense, that later allow wars of movement whereby new powerful actors emerge and strike new alliances. Their struggles require them to co-opt 'experts' in a variety of ways, which channels the evolution of the scientific discourse further. Such mechanisms, illustrated by the Neste Canal, seem to occur globally. Intellectuals or academics in the United States have been shown to tend not to be dissenters or radicals, but rather quite conformists ${ }^{68}$. The mechanisms whereby the fate of their work is embedded in power struggles contribute to explain this.

The Neste Canal was built because of the commercial rivalry between Toulouse, Moissac, Montauban and Bordeau. The social construction of science and technology that formed an integral part of its physical construction included the navigability of the Garonne, the development of hybrid maize, its irrigation and the minimum flow requirement as the basic indicator of the environmental health of rivers. Its construction was part and parcel of the Environment and History 16.1 
changing power relations among the various actors active in the basin. This led to the unforeseen emergence of very powerful farmer organisations and to a management institution, the CACG, that thrives on selling more water and would collapse if irrigation decreased excessively. Its construction and its management contributed to the evolution of the manner experts were embedded within the power relations among the various actors active in the basin. This narrowed the environmental discourse disproportionately to the consideration of the minimum flow requirement and biofuels at the expense of other, scientifically sound, indicators and technologies. These three types of mechanisms constructed the inevitability of the Charlas Dam. The filiation between the Neste Canal and the Charlas Dam may be complex, but remains undeniable.

${ }^{1}$ G. Hardin, 'The Tragedy of the Commons', Science 162 (1968): 1243-8

${ }^{2}$ Corinne Larrue, Analyser les politiques publiques d'environnement, (Paris : L'Harmattan, 2000); Muriel Tapie-Grime, Patrick Moquay, Cecile Blatrix Développement durable et démocratie participative - La dynamique performative locale (Paris : L'Harmattan, 2007) ; Patrice Durant, Penser l'action publique (Paris : L .G.D.J., 1999)

${ }^{3}$ G. Massardier, 'Les chemins contigus et parallèles de la gestion intégrée de l'eau, Instrument de concertation, négociations, fabrique de passeurs, Le cas du Verdon', Montpellier Séminaire SAIAP (2006).

${ }^{4}$ Raymond L. Bryant, Sinéad Bailey, Third World Political Ecology (London: Routledge, 1997).

${ }^{5}$ Bruno Latour, Politics of Nature. How to bring the sciences into democracy (Cambridge MA: Harvard University Press, 2004).

${ }^{6}$ Tim Forsyth, Critical Political Ecology. The Politics of Environmental Science (London: Routledge, 2003).

${ }^{7}$ Forsyth, Critical Political Ecology, 157-164.

${ }^{8}$ Wendy Espeland, The Struggle for Water, Politics, Rationality and Identity in the American Southwest (Chicago: The University of Chicago Press, 1998).

${ }^{9}$ M. Gandy, 'The making of a regulatory crisis: restructuring New York City's water supply', Transactions of the Institute of British Geographers, NS 22 (1997): 338-358; Patrick Bond, Unsustainable South Africa Environment, Development and Social Protest (Pietermaritzburg: University of Natal Press, 2002).

${ }^{10}$ E. Ostrom; R. Gardner, 'Coping with Asymmetries in the Commons: Self-Governing Irrigation Systems Can Work', Journal of Economic Perspectives, 7, 4 (1993) 93-112; Jonathan Mabry (ed.), Canals and Communities Small-Scale Irrigation Systems, Arizona Studies in Human Ecology, (Tucson: University of Arizona Press, 1996).

${ }^{11}$ Gerhard Lichtenthäler, Political Ecology and the Role of Water Environment, Society and Economy in Northern Yemen, King's SOAS Studies in Development Geography (Aldershot: Ashgate Publishing, 2003); David Mosse, The Rule of Water Statecraft, Ecology, and Collective Action in South India (New Delhi

${ }^{12}$ Bruno Latour \& Le Bourhis Jean-Pierre, Donnez-moi de la bonne politique et je vous donnerai de la bonne eau. Rapport sur la mise en place des Commissions Locales de l'Eau, unpublished report, Paris, 1995 ; M. Kaika, 'The Water Framework Directive: A new 
directive for a changing social, political and economic European framework', European Planning Studies, 11,3 (2003), 299-316.

13 Antoine Picon, 'De l'utilité des travaux publics en France aux XVIIIe et XIXe siècle', Acteurs Privés et acteurs publics, une histoire du partage des rôles (Paris: Ministère de l'Equipement, des Transports et du Tourisme, Direction de la Recherche et des Affaires Scientifiques et Techniques, 1994), 129-136.

${ }^{14}$ Guillerme, 'Genèse d'une catégorie dans la pensée de l'ingénieur de la Restauration' Flux Cahiers scientifiques internationaux Réseaux et Territoires, Année 1991, Volume 7, Numéro 6, 5-17.

${ }^{15}$ Montet, 1841, Mémoire à l'appui d'un projet de distribution générale des Eaux de la Neste ayant pour centre le Plateau de Lannemezan. Archives of the Ecole des Ponts-et-Chaussées C 197 (4) 3982

${ }^{16}$ Montet, 1841, Mémoire à l'appui d'un projet de distribution générale des Eaux de la Neste ayant pour centre le Plateau de Lannemezan. Archives of the Ecole des Ponts-et-Chaussées

C 197 (4) 3982.

${ }^{17}$ Montet, Mémoire à l'appui d'un projet de distribution générale des Eaux de la Neste ayant pour centre le Plateau de Lannemezan.

${ }^{18}$ Philippe Marc, Les cours d'eau et le droit (Paris: Editions Johanet, 2006).

19 Bruno Latour, Science in Action (Cambridge, Massachusetts: Harvard University Press, 1987).

${ }^{20}$ Arnoux, 1841, La distribution des eaux de la Neste. Archives of the Chambre de Commerce de Toulouse.

${ }^{21}$ Chambre de Commerce de Toulouse, 1803-1832, Registre des délibérations de la Chambre de Commerce de Toulouse, Archives of the Chambre de Commerce de Toulouse.

${ }^{22}$ Vignolles Citoyen, Girard Citoyen, \& Mamignard Citoyen, 1803, Mémoire, Archives of the Chambre de Commerce de Toulouse.

${ }^{23}$ Chambre de Commerce de Toulouse, Registre des délibérations de la Chambre de Commerce de Toulouse.

${ }^{24}$ Latour, Science in Action, 139.

${ }^{25}$ Chambre de Commerce de Toulouse, Registre des délibérations de la Chambre de Commerce de Toulouse.

${ }^{26}$ Archives of the Deliberations of the Chambre de Commerce de Toulouse, 25 July 1808.

${ }^{27}$ Archives of the Deliberations of the Chambre de Commerce de Toulouse, 13 April 1808

${ }^{28}$ Archives of the Deliberations of the Chambre de Commerce de Toulouse, 15 June 1808

${ }^{29}$ Y. Garb, 'Constructing the Trans-Israel Highway's Inevitability', Israel Studies, 9, 2 (2004): 180-217.

${ }^{30}$ Chambre de Commerce de Toulouse, Registre des délibérations de la Chambre de Commerce de Toulouse.

31 Chambre de Commerce de Toulouse, Registre des délibérations de la Chambre de Commerce de Toulouse.

${ }^{32}$ J.F. Massie, 'Le canal des Pyrénées Projet de Louis Galabert en 1825', Actes du XVè Congrès d'études régionales de la Fédération Historique du Sud-Ouest et de la Fédération des sociétés académiques et savantes (1963):135-147 ; .F. Massie, 'Louis Galabert (17731841)', Bulletin de la Société d'Etudes Scientifiques de l'Aude, 64 (1964): 1-24.

${ }^{33}$ Mr. Arnoux, La distribution des eaux de la Neste, 28 January 1841, Report published by the Chambre de Commerce de Toulouse, Archives of the Chambre de Commerce de Toulouse, p.4. 
${ }^{34}$ Foigne, 1891, Les Canaux du Midi, Etudes de la Chambre de Commerce de Toulouse, Archives of the Chambre de Commerce de Toulouse.

35 Deffes, 1891, Le Rachat des Canaux du Midi, Etudes de la Chambre de Commerce de Toulouse, Archives of the Chambre de Commerce de Toulouse : 9-10.

${ }^{36}$ Deffes, Le Rachat des Canaux du Midi.

37 Antoine Picon, Technological traditions and national identities A Comparison between France and Great Britain during the XIXth Century, Science, Technology and the 19th century state (Athens: Institut de Recherches Néohelleniques, 2000), 13-21, dir: E. Nicolaidis, K. Chatzis

${ }^{38}$ Carraretto, Maryse, Histoire de Maïs (Paris : Editions du comité des travaux historiques et scientifiques, 2005)

${ }^{39}$ Registre des délibérations de la Chambre de Commerce de Toulouse, 25 Floréal an 11.

${ }^{40}$ Registre des délibérations de la Chambre de Commerce de Toulouse, 12 Nivose an 12.

${ }^{41}$ F. Thomas, 'L'introduction et l'expansion des hybrides en France, 1930-1970', Actes du colloque sur 'L'amélioration des plantes, continuités et ruptures' (2002):1-8

${ }^{42}$ Carraretto, Histoires de maïs.

${ }^{43}$ Carraretto, Histoires de maïs.

${ }^{44}$ Christophe Bonneuil, Frédéric Thomas, « Du maïs hybride aux OGM : un demi-siècle de génétique et d'amélioration des plantes à l'INRA », Conference «L'amélioration des plantes, continuités et ruptures », Montpellier, october 2002.

${ }^{45}$ Montet, Mémoire à l'appui d'un projet de distribution générale des Eaux de la Neste ayant pour centre le Plateau de Lannemezan.

${ }^{46}$ Montet, Mémoire à l'appui d'un projet de distribution générale des Eaux de la Neste ayant pour centre le Plateau de Lannemezan

${ }^{47}$ Schéma Directeur d'Aménagement et de Gestion des Eaux Adour-Garonne, page 78

${ }^{48}$ G. Bouleau, 'Le débat sur la qualité de l'eau - Comment des données peuvent devenir des indicateurs?' Ingénieries, 47 (2006): 29-36.

${ }^{49}$ G. Bouleau, 'Le débat sur la qualité de l'eau - Comment des données peuvent devenir des indicateurs?' Ingénieries, 47 (2006): 29-36.

${ }^{50}$ Agence de l'eau Adour-Garonne, Schéma d'aménagement et de gestion des eaux du basin Adour-Garonne (Toulouse : Agence de l'eau Adour-Garonne, 1996), 27.

${ }^{51}$ D. Brockington, 'The politics and ethnography of environmentalisms in Tanzania', African Affairs, 105, 418 (2005): 97-116.

52 Bruno Latour \& Le Bourhis Jean-Pierre, Donnez-moi de la bonne politique et je vous donnerai de la bonne eau. Rapport sur la mise en place des Commissions Locales de l'Eau, unpublished report, Paris, 1995 ; G. Massardier, 'Les chemins contigus et parallèles de la gestion intégrée de l'eau, Instrument de concertation, négociations, fabrique de passeurs, Le cas du Verdon', Séminaire SAIAP (2006).

53 B. Marnot, 'Les politiques d'aménagement du territoire sous la Troisième République', Conférence $d u$ Comité d'histoire, Ministère de l'Equipement, des Transports, de l'Aménagement du territoire, du Tourisme et de la Mer (2003).

${ }^{54}$ Joel S. Migdal, State in Society. (Cambridge: Cambridge University Press, 2001).

${ }^{55}$ Gerhard Lichtenthaler, Political Ecology and the Role of Water, Environment, Society and Economy in Northern Yemen.

${ }^{56}$ Richard Peet, \& Watts Michael, Liberation Ecologies: environment, development, social movements. (London: Routledge, 1996)

${ }^{57}$ Raymond L.Bryant, \& Bailey Sinéad, Third World Political Ecology. (London: Routledge, 1997).

${ }^{58}$ Philippe Marc, Les cours d'eau et le droit. (Paris: Editions Johanet, 2006). 
${ }^{59}$ Bernard Barraqué, Les politiques de l'eau en Europe. (Paris: Editions La découverte, 1995).

${ }^{60}$ Travaux Publics Ponts et Chaussées, 1840, Mémoire sur un projet général d'emploi des Eaux de la Neste, Archives of the Ecole des Ponts et Chaussées.

61 Zygmunt Bauman, Legislators and Interpreters On modernity, post-modernity and intellectuals. (Cambridge: Polity Press, 1987).

62 Jean-Jacques Pérennes, L'eau et les hommes au Maghreb. Contribution à une politique de l'eau en Méditerranée. (Paris: Karthala, 1993).

${ }^{63}$ Bauman, Legislators and Interpreters On modernity, post-modernity and intellectuals.

${ }^{64}$ Foigne, Les Canaux du Midi.

65 Société d'agriculture de Haute-Garonne, 1864, Fiche de Renseignements pre-imprimée remplie par la société d'agriculture. Unpublished, Archives départementales de Toulouse.

${ }^{66}$ T. Ruf, 'Droits d'Eau et Institutions communautaires dans les Pyrenees-Orientales. Les tenanciers des canaux de Prades (XIVe-XXe siecle)', Histoire et Societes Rurales, 16 (2000): 11-44.

${ }^{67}$ Travaux Publics Ponts et Chaussées, Mémoire sur un projet général d'emploi des Eaux de la Neste.

${ }^{68}$ Steven Brint, In an Age of Experts The changing role of professionals in politics and public life. (Princeton: Princeton University Press, 1994). 